\title{
Property rates as an instrument for development: an analysis of South African policy, law and practice
}

\author{
Jaap de Visser $^{1}$
}

When local governments impose property taxes, their primary objective is to fund their expenditure. However, the role of local government can be seen as far more than simply the provision of local public services. Local government can be an agent of its community, responsible for using its authority in a manner that creatively responds to local needs and thereby enhances the well-being of its area. This chapter asks if this interpretation of the role of municipalities has consequences for the manner in which they tax properties.

South African municipalities have recently been equipped with a new property rates framework, which permits them to differentiate between categories of properties and to legislate for various kinds of property rates discounts. This framework presents a new approach to the use of property rating, by positioning it as an instrument with a stated developmental objective in addition to its revenue-raising function.

This chapter therefore examines to what extent and how South African municipalities actually use their power to levy property rates as a developmental instrument. Do they use property rates as an instrument to reduce poverty, facilitate access to economic opportunities and encourage sustainable use of resources? Or does property tax remain an instrument primarily deployed to raise revenue that funds service delivery? In attempting to answer these questions, the author was limited by the lack of independent research on this topic, and draws primarily from official reports.

First, a brief introduction to local government in South Africa is given. An overview of the legal and policy framework for the levying of property rates then follows, including the expectation implicit in that framework that municipalities should use property rating in a developmental manner. The chapter then proceeds with a discussion of some of the limits and concerns with respect to such use of property taxation. Finally, it canvasses some of the policy innovations in municipal property rating.

\subsection{Local government in South Africa}

Before 1994, local government in South Africa was designed to implement apartheid. Local government institutions were racially determined and the black majority was denied democratic rights. White municipalities were self-serving entities; they were given exclusive power to tax properties in well-resourced and viable commercial centres, without any 
obligation to use the revenue to improve the lives of township dwellers. Black municipalities were undemocratic and starved of income and authority.

They became the subject of large-scale service boycotts in the 1980 s. $^{2}$ The 1993 constitution introduced major reforms: local government was given constitutional recognition and various local government institutions were merged (Steytler and De Visser 2007). Even more fundamental change came with the 1996 constitution, which further entrenched the role of local government. The new system was put into operation in 2000, and now comprises a democratically elected political leadership (section 157 of the constitution) with constitutionally guaranteed authority over listed functional areas (section 156). The constitution also secures local government's authority with regard to certain important financial matters. It empowers municipalities to impose surcharges on fees for services provided and to impose property rates (section 229), and entitles local government to an 'equitable' share of nationally generated revenue (section 214).

\subsubsection{Developmental local government}

As an unequivocal response to the destructive role played by local government in the past, the constitution posits local government as a sphere of government that is responsible for important developmental matters. The constitutional 'objects of local government':

- provide democratic and accountable government for local communities;

- ensure provision of services to communities in a sustainable manner;

- promote social and economic development;

- promote a safe and healthy environment; and

- encourage the involvement of communities and community organisations in the matters of local government (section 152).

Municipalities are furthermore instructed to give priority to the basic needs of the community (section 153). The 1998 White Paper on Local Government defined this developmental mandate as 'local government committed to working with citizens and groups within the community to find sustainable ways to meet their social, economic and material needs and improve the quality of their lives' (Department of Constitutional Development 1998: 17). According to the White Paper, the main characteristics of developmental local government are:

- maximising social development and economic growth - stimulating local economies and job creation;

- integrating and co-ordinating the efforts of all developmental actors - mainly through integrated development planning;

- democratising development - harnessing the input and energy of local citizens; and

- leading and learning - building social capital at the local level to enable local solutions to development problems (ibid: 18 ). 
The key outcomes that the White Paper envisages developmental local government achieving are:

- provision of household infrastructure and services;

- creation of liveable, integrated cities, towns and rural areas;

- local economic development; and

- community empowerment and redistribution.

\subsubsection{Local government institutions}

South Africa's land mass spans around 1.2 million square kilometres, inhabited by close to 48 million people (Statistics South Africa 2007). Yet the country has only 278 municipalities, making South Africa home to some of the world's largest local governments in terms of both area and population. 3 There are three types of municipalities: metropolitan, district and local. There are eight metropolitan municipalities, which are single-tier local government structures.

Outside these areas the country is divided into 44 district municipalities. Each district comprises a number of local municipalities, usually between three and five. There are 226 local municipalities in total.

Municipalities are responsible for important services such as water and sanitation, local roads, refuse removal, town planning, electricity reticulation and environmental health services. They develop and maintain parks, recreational facilities, markets and local transport facilities. In addition to these constitutionally guaranteed functions, they often perform further functions including housing delivery, primary healthcare and community services such as developing and running libraries and museums. Taken together, these functions position local government at the epicentre of much-needed physical and social development in South Africa.

As directed in the Local Government: Municipal Systems Act (2000), municipalities must produce and annually review Integrated Development Plans (IDPs), which are intended to be the building blocks for the entire government's service delivery and infrastructure planning.

\section{Property taxation}

Property taxation is an important source of revenue for municipal services and, as indicated earlier, has been constitutionally guaranteed as a taxing power for municipalities. Historically, property rates have always been an important mechanism to fund municipal services, albeit as part of a diversified basket of revenue sources and not across the board. Kihato and Berrisford (2006: 33) note that under apartheid tax collection in white municipalities was 'generally high and well received', in part because residential owners enjoyed generous rebates and the substantial profits generated from the provision of electricity and water made up for the loss of income. 
Property taxation in rural areas was largely non-existent before the recent changes to the local government and property-rating regime. The White Paper remarks that 'while [it] is by no means the sole source of municipal revenue, it is an important source of discretionary own revenue' (Department of Constitutional Development 1998: 114). Municipalities rely on property rate income to fund other services, access to which is not limited to specific consumers.

Nevertheless, the White Paper expects municipalities to use their powers to levy property rates for more than simply raising revenue. It refers to the 'need to develop the criteria for evaluating alternative property valuation systems, within the framework of alleviating and addressing poverty' (ibid: 115). It also warns that this must be subject to clear policies and procedures, and that any tax relief 'should be clearly indicated in a transparent and consistent manner in the budget of a municipality' (ibid).

Furthermore, the White Paper noted the importance of latitude for municipalities 'to make certain decisions concerning the nature of the property tax in their area of jurisdiction, which reflect their unique circumstances and local economic objectives' (ibid). By 1998 the policy intention was thus that municipalities would deploy the instrument strategically to achieve developmental outcomes. As discussed below, the legal framework still leaves considerable discretion to municipalities to make decisions in this regard.

\subsubsection{The current context: local government 'in distress'}

The constitutional, statutory and policy framework for local government in South Africa is sound and the progress made to date is impressive. 4 However, the challenges remain daunting. Many municipalities battle huge service delivery and backlog problems. Communication and accountability relationships with communities are often poor, and many municipalities experience internal governance issues and sometimes even corruption and fraud (Department of Cooperative Governance and Traditional Affairs 2009). Municipalities are often characterised by poor financial management, resulting in negative audit opinions (Department of Cooperative Governance and Traditional Affairs 2009). A lack of scarce skills such as engineering, financial management and planning seriously frustrates the ability of municipalities to implement their developmental mandate (ibid). Communities across South Africa are dissatisfied with the progress made. The image of communities protesting against service delivery backlogs, maladministration and corruption has become a common occurrence. Recent research indicates that, from 2007 to 2011, there was an average of 11.6 protests per month in South Africa, but the first eight months of 2012 averaged 28.3 protests. Not only is the number of protests on the increase, they are also becoming more violent, with 79.2 per cent of protests turning violent in the first eight months of 2012 (De Visser and Powell 2012). It is clear that local government is in distress.

Another manifestation of dissatisfaction with local government performance is the phenomenon of ratepayers withholding the payment of property rates and service fees. While community protests generally originate in the townships, the withholding of payments is led by well-organised ratepayers' associations, generally comprising middle- and upper-class

\section{https://repository.uwc.ac.za}


residents. In response to administrative malaise and the lack of service delivery, ratepayers declare disputes with the municipality and cease paying their taxes. Instead, the moneys are paid into a common bank account and released to the municipality only when service delivery improves (Powell et al. 2009).5

Property rating by municipalities thus takes place within a context of a promising institutional framework, but with serious problems in terms of local government's capacity to implement the system effectively. Indeed, many rural municipalities do not levy any property rates at all, despite their constitutional authority to do so. High levels of poverty and the difficulties of valuing properties and administering the tax are cited as reasons for the absence of property rating in rural areas (National Treasury 2011).

\subsection{Legal and policy framework for property rating}

As noted earlier, section 229 of the constitution empowers a municipality to impose rates on property. This constitutional guarantee manifests itself in at least two ways:

- First, the power of a municipality to impose a rate on property stems from the constitution itself ${ }^{6}$ and is described by the Constitutional Court as an 'original' power.7 Before the interim constitution, all municipal powers, including the rating power, were 'delegated' powers conferred on a local authority by another organ of state. ${ }^{8}$

- Second, even though the constitution also enables the national government to regulate this power, such regulation must respect municipal discretion to establish policy and determine rates. For example, legislation in the Eastern Cape which required provincial permission for the imposition of a rate of over two cents in the rand was struck down in CDA Boerdery (Edms) Bpk $v$ Nelson Mandela Metropolitaanse Munisipaliteit. The Supreme Court of Appeal held that this requirement was a product of the pre-1994 dispensation, 'tailored to its hierarchy and matched to the Administrator's supervisory control over municipalities and his executive role in relation to them.'9 Under the 1996 constitution, the judge continued, the Premier enjoys no 'special supervisory powers over the exercise of local government functions, or special duties in relation to the determination of rates.' 10

This does not mean that the municipality's power is unfettered. Section 229 of the constitution itself provides that the rating power 'may not be exercised in a way that materially and unreasonably prejudices national economic policies, economic activities across municipal boundaries, or the national mobility of goods, services, capital or labour'. Second, the Local Government: Municipal Property Rates Act (MPRA) of 2004 contains a framework within which municipalities must perform the property rating function.

Under the MPRA, only metropolitan and local municipalities may levy property rates. Rates are levied on land and improvements, and the owner of immovable property is liable to pay the property rates to the municipality. The market value of the property is the basis for valuation, which is carried out by professional valuers. 
Municipalities determine the tax rate and, importantly, the rate may differ from one category of properties to another. However, as indicated above, municipal discretion is subject to certain limitations imposed by the constitution and national government.

For example, under the MPRA national government may set an upper limit on the percentage by which rates in the rand (R) for specific categories may increase. The national government may also set an upper limit on the percentage by which the total revenue derived from rates in all or specific categories may increase. Furthermore, the national government may determine maximum ratios with respect to differential rating and has indeed promulgated those.

\subsubsection{Reliance on property rates}

User charges (electricity, water, sanitation and refuse) are by far the largest contributors to municipal revenue (National Treasury 2011: 58; 2007: 13; Tshangana-Hickey 2009: 5). National transfers are the second largest source of revenue for local government, calculated at 32.6 per cent in the 2009/10 budget year (National Treasury 2011: 59).

Property rates come in third, but the fact that a large proportion of user charges levied by municipalities has to be paid over to bulk providers (National Treasury 2011: 58) and that a significant proportion of national transfers are conditional ${ }^{11}$ emphasises the important role that property rates income plays in the municipal budget. The municipality depends on this income to fund services for which no user charge can be levied. Examples are municipal roads, parks, street lighting and storm-water systems (National Treasury 2011: 40).

Broadly, property rates form about one fifth of the operating budget of a metropolitan municipality and about 15 per cent of the operating budget of a local municipality (National Treasury 2007: 14, 17; Tshangana-Hickey 2009: 5). Income from property rates grew at a modest pace between 2001 and 2009, and this income stream held up well during the Global Financial Crisis (National Treasury 2011: 58-59). Property rates as a percentage of the country's gross domestic product (GDP) have remained constant at about 1 per cent (National Treasury 2011: 50).

The introduction of the MPRA, with its full effects felt only from 2008, is predicted to accelerate the growth of property rates income. The National Treasury expected a 10 per cent increase in property rates income in the medium term (National Treasury 2007: 14, 17; 2011: $60)$.

The extent to which municipalities actually collect the property rates that are due to them is difficult to measure for a number of reasons. First, municipalities generally issue a composite account, which may comprise water, sewage and electricity charges along with property rates. Defaults on that account are not immediately attributed to any specific item, so that reporting on fiscal efficiency does not separate property taxation from service charges. Second, both the system and scope of property valuation have undergone drastic changes in recent years. Comparisons between the potential of these new valuation rolls and the actual

\section{https://repository.uwc.ac.za}


collection of property rates have hardly been made yet, let alone aggregated to figures that represent general trends.

However, while the specific rates portion of consumer debt may not be easily identified, there is ample evidence for the assertion that the overall debt (including both property rates and service charges) is massive. ${ }^{12}$ This consumer debt is a serious impediment to municipal operations. It can be attributed to a combination of failing revenue management (integrity and accuracy of billing systems) on the part of municipalities (National Treasury 2011: 68); unwillingness to pay on the part of consumers (National Treasury 2011: 209) and sometimes government departments; but also to the impact of poverty on the ability to pay. Any municipal efforts to use property rating for developmental purposes will need to be accompanied by improvements in fiscal efficiency. ${ }^{13}$

\subsubsection{Municipal property rates policies}

The MRPA requires every council to adopt a binding property rates policy, which must contain and give insight into policy choices the municipality is making when levying rates. The MPRA also instructs municipalities to pursue local, social and economic development in their property rates policies. The law thus envisages that municipalities use their property rates policies in a developmental manner. The MPRA more specifically places a number of demands on the content of the policy. For example, the policy must take into account the effect of rates on the poor ${ }^{14}$ and include appropriate measures to alleviate their rates burden.15 Relief cannot be granted other than in accordance with the policy. The impact on public benefit organisations must also be considered, and the policy must take into account the effect of rates on public infrastructure. ${ }^{16}$ In addition, the Act requires special consideration of agricultural properties: the extent to which they receive services, contribute to the local economy and assist in meeting development obligations, and the contribution that is made by them to the welfare of farm workers, a particularly vulnerable group in South Africa.

The policy must furthermore set out the system of differential rates for different categories of properties, ${ }^{17}$ and provide criteria for any differentiation between categories of properties or owners of properties for the purposes of rates exemptions, rebates or reductions, or increases in rates. Exemptions, rebates and reductions must be identified and motivated in the policy. ${ }^{18}$ Finally, the policy must provide information about the impact that the MPRA and the municipality's own policy decisions will have on the level of rates revenue.

On the adoption of a rates policy, the municipality must pass a by-law to give effect to its implementation. This ensures that the choices made in the policy can be made legally binding on the municipal community. The policy and the by-law are long-term strategies. Actual rates are determined annually with the passing of a property rates resolution setting the rates for the different property categories. 
This chapter focuses on the use of property rates as an instrument to facilitate development. It is therefore prudent to briefly introduce the menu of instruments from which a municipality may choose to differentiate or provide tax relief.

\subsubsection{Differential rating}

As indicated earlier, the law allows municipalities to apply differential rates, and municipalities have significant leeway in adopting differential rating regimes. They may choose a method of identifying categories, identify categories from a predetermined list and add their own categories (Steytler and De Visser 2007: 13-34). Forthcoming changes to the MPRA suggest this leeway will be reduced in that municipalities will be limited to choosing from a predetermined list of categories (Local Government: Municipal Property Rates Bill 2011). Also as noted previously, the extent to which the rating may differ across categories is curtailed by the promulgation of maximum ratios by the national government.

Bird and Slack identify three grounds to justify differentiated taxes. First, fairness may dictate that the tax should correlate to the benefits received from local public services (Bird and Slack 2004: 37). This is true for South Africa. Certain categories of properties, such as agricultural properties, tend to receive fewer benefits from local public services than residential properties or business properties. Second, the local government may want to impose a higher tax on the tax base that is 'least elastic' (Bird and Slack 2004: 37). In South Africa, the identification of business properties as a distinct category that is 'less elastic' has enabled municipalities to impose a higher rate on those properties. The third justification mentioned by Bird and Slack is particularly relevant in the context of this chapter, namely that variation can be used to achieve land use objectives (Bird and Slack 2004: 37). Property taxation then moves beyond the mere collection and redistribution of income to attempting to influence behaviour. The most common example in South Africa is the imposition of a higher rate on vacant land as a distinct category, in order to stimulate development and discourage speculation.

\subsubsection{Exemptions}

As with any property rating system, certain properties are exempt from rating.

Municipalities may identify specific categories of properties or property owners for exemption, while some exemptions are already granted by the national government. The MPRA defines certain generic exemptions, such as nature reserves, mineral rights and places of worship.

Exemptions have been criticised in international literature because they narrow the tax base of municipalities. Therefore, the taxes on the remaining taxpayers must be increased or the level of local services must be decreased. Additionally, they are likely to result in disproportionate tax burdens. This is troublesome, especially when a higher-level government determines what is exempt (Bird and Slack 2004: 26).

In South Africa, it is becoming common for the national government to pursue its national policy objectives by imposing exemptions which municipalities are then obliged to follow. Its

\section{https://repository.uwc.ac.za}


constitutional power to 'regulate' property taxation permits national government to do this. For example, nature conservation, a responsibility of national and provincial governments, may be pursued by prohibiting municipalities from levying property rates on property classified as such. This is discussed further below.

\subsubsection{Reduction}

As indicated earlier, rates are calculated annually on the full market value of a property. However, the municipality may, with respect to a category of properties or property owners, subtract an amount from the market value, thereby reducing the rates liability. ${ }^{19}$ Some reductions are mandatory, but the municipality may also, in terms of its rates policy, add to the list. In terms of developmental objectives, an important generic reduction is the so-called 'residential exclusion'. The MPRA excludes the first R15, ooo of every residential property from the rateable value of that property, and thus introduces a very mild form of graduated property rates.

\subsubsection{Rebates}

Municipalities may grant rebates to specific categories of properties or property owners. These do not affect the rateable value of the property or the rate that applies to it. Rather, they are discounts granted by the municipality on the ultimate rates liability with respect to a specific property. Rebates are often granted on the basis of an application made to the municipality and may therefore involve considerable administrative effort. It is usually the profile of the owner, rather than the profile of the property, that attracts the rebate (Steytler and De Visser 2007: 13-39). The municipality must set out criteria for rebates in its rates policy. It is free to formulate its own categories, but the Act lists owners that are indigent, dependent on social welfare, temporarily without income or struck by disaster as examples of categories of owners that may be considered for rebates. Importantly, the Act also lists 'bona fide farmers' as possible recipients of rebates.

\subsubsection{Accounting for discounts}

Transparency and accountability in the reduction of property rates liability for specific categories is critical (Bird and Slack 2004: 26). Bird and Slack advise that the properties in question should still be valued so that the municipality can be clear about the taxes that could have been collected.

This principle was already expressed in the 1998 White Paper (see above) and is followed in South African law. The MPRA requires all exemptions, reductions and rebates granted by the municipality to be listed and tabled by the municipal council.

The municipality must indicate the implicit cost of all exemptions and rebates in an annual statement, and projections regarding revenue to be foregone must be included in the annual budget.

\subsubsection{Expectations: South African national and provincial policy frameworks}

Various national and provincial policy frameworks are expressing the expectation that municipalities use property rating as an instrument to stimulate local economic

\section{https://repository.uwc.ac.za}


development. The White Paper on Local Government and its reference to the developmental use of property rating was discussed earlier in this chapter. The National Framework for Local Economic Development, a more recent policy statement, remarks that in promoting the local economy, the primary focus of municipalities should be upon [among other things] managing a progressive property tax system' (Department of Provincial and Local Government 2005). Furthermore, the framework lists property rating as an instrument that municipalities can use when they compete among themselves 'to get the best out of each area' (Department of Provincial and Local Government 2005: 15). The framework itself does not provide any advice to municipalities as to how best to use property rating to achieve these objectives.

Another example is the Western Cape Rural Land Use Planning and Management Guidelines, which envisage that municipalities will incentivise the consolidation of conservation estates through property rates discounts (Western Cape Department of Environmental Affairs and Development Planning 2009: 23). Therefore, there is an expectation that municipalities will choose to forfeit revenue to achieve nature conservation objectives, despite the fact that nature conservation is not part of a municipality's mandate.

\subsection{Arguments against using property rates for developmental purposes}

It is clear that South African municipalities must use their power to differentiate and offer property rates discounts in a balanced manner. However, the international literature appears to view differentiation and the granting of property rates relief with a dose of scepticism. Some of the most important arguments used to caution against liberal use of property rates differentiation and discounts are discussed below.

One of the most important determinants of a successful property rates regime is the administration of it. According to Bird and Slack, "[n]o area of taxation is more dependent on administration' (2004: 41). A property rating system should thus not be unduly complicated and it should be relatively easy for local officials to administer. The imposition of a myriad of different rates and instruments for granting tax relief could complicate the rating system. This dimension is particularly relevant in the South African context. The property rates regime is new, and skilful and experienced administrators, necessary to implement and administer complicated tax relief instruments, are in desperately short supply.

Transparency and certainty are also key values in property rating (Bird and Slack 2004: 40). If differentiation and tax discounts result in a lack of transparency and their administration is vulnerable to capture by local groups or individuals, they may become an instrument to benefit individuals or individual institutions rather than a strategy to achieve development. Similarly, property taxpayers should be able to ascertain, with a degree of certainty, how the property tax regime operates and how the criteria for differentiation or discounts will be applied to them. A lack of certainty will generally disadvantage taxpayers, and incentives do not work if it is unclear when they apply.

\section{https://repository.uwc.ac.za}


It is sometimes argued that property rates differentiation and rates relief are likely to create unwanted distortions. First, the differentiation is not always based on the level of municipal services received. Therefore, landowners may face different treatment while using the same level of municipal services. Second, the differentiation may have implications for economic competition: differential treatment means that owners or managers of taxed properties face higher costs than those of exempt properties (Bird and Slack 2004: 5).

Municipalities may want to use property rates relief to encourage activities that are particularly desirable from a developmental point of view. While acknowledging the need for favouring certain property holders to encourage their presence in the local community, Bird and Slack argue against the use of property tax exemptions to achieve this: they express a preference for direct grants in that context (2004).

Attempts to incentivise behaviour and mitigate rates liability often reduce the municipality's revenue from rates. It may be argued that local revenue generation is too precious a commodity to sacrifice at the altar of local policy-making and local redistribution. Local revenue generation is not only critical to enable the funding of local public services, but also indispensable to establish local accountability for those public services. Yet local governments are often the first to be requested or instructed to give up their own revenue, be it in response to national anxiety or as part of a tax relief effort.

One of the reasons for municipalities to use property rates differentiation or discounts is to redistribute resources from wealthier to poorer communities within their areas. However, in intergovernmental fiscal policy circles it is often argued that redistributive efforts are best administered at the central level. Decentralisation of revenue generation has the potential to aggravate regional inequity (Fjelstad 2001: 148), and sceptics of redistribution at the local level argue that localised decision making surrounding revenue generation tends to ignore externalities (Ajam 2001: 126; Prud' Homme 1994: 15). Even property taxation, as an immovable tax, is not immune from that effect. For example, higher property taxation of businesses may make sense from a redistributive perspective, but the cost impact of that taxation may be exported to consumers of the relevant goods and services outside the municipality (Bird and Slack 2004: 39).

On the other hand, it may be argued that an outright rejection of any redistributive role for local government can no longer be supported, given the momentum towards a role for municipalities that moves beyond the quest for the most efficient retailer of services into a broader well-being or developmental objective that inevitably implies redistributive elements. ${ }^{20}$

In South Africa, both the policy context and the size of municipalities signal a clear departure from the position that local governments have no redistributive role. Policy and legislative instruments governing local government in South Africa are awash with references to redistribution. The White Paper on Local Government lists 'community empowerment and redistribution' as one of the developmental outcomes of local government. ${ }^{21}$ Municipal

\section{https://repository.uwc.ac.za}


boundaries must be demarcated with the need to share and redistribute financial and administrative resources' in mind.22 Indeed, a radical transformation of local government boundaries has followed, as illustrated by Table 7.1.

As noted earlier, South Africa's municipalities rank among the world's largest and arguably are thus well positioned to perform a redistributive role. However, while the attempt to influence behaviour with taxation policy may be a dominant feature of national taxes, the same may not hold true for property taxation by local governments.

\section{Table 7.1 Total number of municipalities in South Africa}

\begin{tabular}{llllll}
\hline Timeline & 1994 & $1994 / 95$ & 2000 & 2006 & 2011 \\
\hline Number of municipalities & $>2,000$ & 842 & 284 & 283 & 278 \\
\hline
\end{tabular}

Bird and Slack argue that the level of property rates is generally set to make up the shortfall between expenditure requirements and revenue from other sources: 'Local governments first determine their expenditure requirements. They then subtract nonproperty tax revenues available ... from their expenditure requirements to determine how much they need to raise from property tax revenues. The resulting property tax requirements are divided by the taxable assessment to determine the property tax rate' (2004: 33; see also Steytler and De Visser 2007: 13). If property taxation is thus primarily aimed at ensuring that the municipality is able to fund service delivery and developmental activities from the expenditure side of its budget, the room to manoeuvre is necessarily limited when it comes to the setting of differential rates and the determination of tax relief measures.

This approach to setting a specific tax rate undoubtedly rings true for many local government practitioners in South Africa. Nevertheless, it is clear that the constitutional and legal framework expects more. Municipalities are tasked to carefully consider and consult communities on a property rates policy and pursue developmental objectives in that policy. This policy will have set the scene before the specific tax rate or differential tax rates can be set by the municipality.

Another concern is the danger of expecting too much impact from property rates variation and relief on, for example, business decisions (Bird and Slack 2004: 39). If property rates account for a small proportion of business costs, a tax variation or discount is unlikely to prompt businesses to change their behaviour or their location.

In that context, it is important to note that in South Africa the overall municipal account (including rates and tariffs) falls below the international benchmark of 15 per cent of household income (Tshangana-Hickey 2009: 8). It is not unreasonable to deduce from that that property rates are also unlikely to take up large chunks of business expenditure.

In addition, the extent to which municipalities can link the property rates instrument to local economic development may be limited by the regulatory framework. For example, in South

\section{https://repository.uwc.ac.za}


Africa municipalities are prohibited from rating any below-ground structures used for mining. This puts a large section of the economy beyond their reach. It prohibits municipalities from reaping the benefits of underground value and limits the municipality's ability to influence a mining company's decision-making through taxation policy.

\subsection{A review of current South African practices}

In order to examine how South African municipalities are making use of the opportunities for property rates differentiation and rates relief, and how they aremitigating the risks and concerns mentioned above, the policies of the 20 largest municipalities were examined. Policy strategies were organised into those that impact the demand side (efforts to mitigate rates liability for vulnerable groups) or the supply side (efforts to support or stimulate certain behaviour or enterprise) of the property market.

The analysis reveals from the outset that the new system of the MPRA, with its closely defined instruments for differentiation, has not yet fully translated into coherent property rates policies across the board. Some of the policies make use of the various instruments in a confusing manner. For example, when Ethekwini ${ }^{23}$ promises to rate sporting bodies only on their buildings, this appears to be contrary to the MPRA's principle of rating land and improvements. A more innocuous example is Cape Town's 100 per cent rebate on religious properties, which is eclipsed by the MPRA's statutory exemption of religious properties. These are indications that municipalities are still coming to terms with the instruments contained in the MPRA property rates framework.

Many of the policies contain discretionary rebates, but often the actual discount offered by the municipality appears to be a matter decided on the basis of criteria that are not included in the property rates policy. This may give rise to disagreements, but more importantly it detracts from the transparency of the property rates scheme. For municipalities to maintain a credible property taxation system, more clarity needs to be provided in the policies themselves - lest the discount become simply a matter of negotiation between the property owner and the municipality.

What becomes clear upon comparing the policies is that, with regard to certain issues, there is considerable variation in approaches among municipalities. For example, some municipalities (such as Emfuleni and Mbombela) ${ }^{24}$ impose a higher rate on vacant land in order to stimulate development and discourage speculation. However, municipalities such as Msunduzi ${ }^{25}$ and Ethekwini appear to do the opposite by reducing the tax burden on vacant land. Another example is the treatment of state property: some municipalities offer rebates to state institutions (Johannesburg) while others levy additional rates (Emfuleni, Mbombela). Assuming that this variation is a result of well-considered policy choices, the importance and usefulness of local discretion is underscored.

Few municipalities appear to use property rates as an instrument to influence behaviour related to specific geographically determined areas within the municipality. In other words, few use property rating as a spatial planning instrument. Most geographically targeted

\section{https://repository.uwc.ac.za}


discounts refer to areas that have been struck by disaster. The sample included only three rebates for property in designated areas such as industrial zones or urban development zones (Mbombela, Emahlahleni, Mangaung). ${ }^{26}$ The City of Johannesburg's policy includes an incentive for people to move into the inner city: rezoning into residential use in the inner city is awarded with a rebate.

The property rates policies contain a variety of measures to mitigate the rates burden on institutions that perform activities that are socially desirable, such as:

- caring for the aged;

- offering education (public and private schools, universities);

- culture and history (museums, libraries, monuments, art galleries);

- performing charity and welfare activities;

- caring for animals; and

- providing sports activities.

Many municipalities in the sample include measures that target vulnerable groups. Most policies contain exemptions or rebates for indigent persons. Often, qualification for these rebates is linked to registration on the municipality's indigent register - a comprehensive list of residents maintained by the municipality to enable it to differentiate when it collects fees for services. Additional criteria (such as a maximum property value) may sometimes apply.

The extension of the statutory residential exclusion of $\mathrm{R} 15$, ooo to a more generous level is a common occurrence in the sampled municipalities. This is a measure designed to mitigate rates liability for poor households. In an extreme case, Cape Town has increased the exclusion to R200, 000. A number of other municipalities have set the level between R40, ooo and R8o, ooo.

Hickey-Tshangana discusses the residential exclusion and concludes that the effect is that many poor households escape the rates burden altogether. She concludes that the residential exclusion is by far the easiest form of rates relief to administer and that it is reasonably effective in targeting the poor. She also concludes that the effect on revenue generated is minimal, as the rates income from that property segment is modest. For example, while the residential exclusion in Johannesburg removed almost a third of the number of properties from the radar screen, their combined property value represented no more than 2 per cent of the entire valuation roll (Hickey-Tshangana 2009: 17). The conclusion may be that residential exclusions are a particularly attractive 'poverty alleviation' tool in a developing context. First, the demands on tax administration are modest. Second, large income and wealth disparities work in the municipality's favour by producing a large pool of beneficiaries while limiting impact on revenue.

Sometimes, specific vulnerable groups are identified in the policies that were reviewed. For example, 7 of the 20 policies contain specific rebates or exemptions for child-headed households, a particularly pernicious phenomenon often associated with under-

\section{https://repository.uwc.ac.za}


development, migrant labour and the HIV/AIDS pandemic. Even more common is the rebate for pensioners and people with disabilities.

\subsubsection{Encouraging developmental behaviour}

Direct encouragement of 'developmental behaviour' can be found in the treatment of agricultural properties. Municipalities clearly attempt to incentivise decent treatment of farm workers, a particularly vulnerable group in South Africa. The sample includes rebates for:

- offering permanent employment (one case);

- providing housing to farm workers (four cases);

- providing water to farm workers (five cases);

- providing electricity to farm workers (five cases); and

- providing other educational/recreational services (four cases).

\subsubsection{Stimulating local economic development}

The sample includes a number of measures that are aimed at stimulating local economic development by reducing the rates liability of particular enterprises. Ethekwini and Mbombela encourage the tourism industry by including a rebate for bed and breakfasts and guesthouses. Mbombela also offers a rebate to micro businesses, plus one for farming activity that contributes to the local economy. Three local municipalities (Makhado, Matjabeng and King Sabata Dalindyebo) ${ }^{27}$ have a rebate for enterprises that conform to their local social and economic development policies.

However, these examples of rates discounts that aim to directly stimulate economic development are not encouraging. Apart from the rebate for tourism accommodation, the discounts are loosely defined. It is not clear what a 'micro business' is. Similarly, a farmer's contribution to the local economy appears to be either a given or extremely hard to determine. Finally, it is unlikely that a local business will be able to make an informed assessment of whether it perhaps conforms to the social and economic development policy of the municipality and should therefore apply for a rebate, let alone include the rebate in its business calculations.

The sample also includes an interesting measure in Mbombela Municipality, which assists property owners to weather the storm of a recession by offering a rebate 'to assist owners with the current economic situation'.

\subsection{Summary and assessment}

The constitutional and statutory framework for property rates in South Africa permits and expects municipalities to use their authority to levy property rates in a developmental manner. In South Africa, property rates differentiation and rates relief are viewed as an expression of a developmental state, which is expected to intervene in a balanced manner to correct distortions in the economy and society. These include serious distortions in the South African economy, including gross racial imbalances, huge income disparities and a dominance of large economic institutions (African National Congress 2007). Municipalities

\section{https://repository.uwc.ac.za}


thus operate from a firm ideological and policy basis when they engage in making policy on property rating.

International literature cautions against overzealous use of property rating to achieve developmental outcomes, and emphasises the need for municipalities to protect and carefully administer their revenue sources. However, the review of the property rates policies of the 20 largest municipalities shows that they are indeed making use of the opportunity offered by the legal framework to differentiate and offer rates relief to achieve policy objectives. The policies reveal a considerable array of differentiation between property categories, often with a view to redistribute resources. They also include a number of tax relief measures aimed at poverty alleviation and the promotion of economic, social and cultural development.

The policies can be critiqued for often employing differentiation and tax relief measures without a clearly stated policy rationale. The effectiveness of these instruments also varies. The exclusion of an initial amount of residential property value from rating is easy to administer and appears to assist in reducing poverty without resulting in huge amounts of revenue being lost to the municipality, particularly as part of the exclusion is for rates that the municipality would in all likelihood not be able to collect in any event. Some of the rebates to encourage local economic development are not particularly well designed and probably not realistic. Common criteria such as 'compliance with the local social and economic policy' and 'making a contribution to the local economy' are somewhat arbitrary and difficult to implement. From a tax administration point of view, they appear problematic and are not likely to go far in facilitating local economic development.

By providing relief to institutions that provide important social or cultural services, municipalities may encourage their presence and facilitate their work. These relief measures are not necessarily new and probably compare well with how local governments elsewhere levy property rates (albeit usually through centrally imposed limitations). The measures adopted to encourage the decent treatment of farm workers are examples of innovative use of the rebate instrument. It is important to note, however, that these mechanisms are suggested in the MPRA itself. This indicates that municipalities still rely heavily on the national framework for ideas.

Apart from the occasional reward for densification, few municipalities have included instruments directly aimed at encouraging sustainable use of resources. This appears to be an area where more policy innovation may be possible.

The apparent reluctance on the part of municipalities to innovate must be understood within its context. First, this assessment may have come too early. The property rates regime is new and required municipalities to implement significant technical reforms in, among other things, property valuation. To date, no comprehensive evaluation has been conducted of the impact of the new property rates regime and the policy objectives it is meant to serve. It is expected that over time attention will shift from managing the transition to exploiting the scope for policy innovation.

\section{https://repository.uwc.ac.za}


Second, a key question is to what extent the use of exemptions, rebates and exclusions is actually costing municipalities' revenue. As indicated earlier, the municipality is instructed to make provision in its budget for revenue to be foregone as a result of rates alleviation, and to report on this item. Research on the computation of these municipal figures has not yet been conducted and falls outside the scope of this chapter. A system-wide assessment is thus difficult to make. However, it does appear that municipalities are reporting significant 'revenue costs' in the form of revenue foregone as a result of rates alleviation. ${ }^{28}$

Third, while municipalities in South Africa may enjoy constitutional protection, their own revenue sources are continuously under threat. For example, the national government seriously considered removing electricity distribution from local government. The perennial challenge of debt owed to municipalities may also make municipalities reluctant to be liberal with tax relief. 29

Fourth, there are serious institutional constraints that prevent municipalities from using property taxation to its full potential. Property rating in rural areas is still in its infancy, given the levels of poverty, the difficulties in valuing properties and the challenge in administering the tax (National Treasury 2011: 208). The low level of trust in municipalities, ${ }^{30}$ which has resulted in widespread unwillingness to pay, also seriously undermines property rating as a means to generate revenue and influence behaviour (National Treasury 2011: 209).

Fifth, many municipalities face capacity constraints in the area of financial management. The National Treasury bemoans 'a general lack of the technical skills and knowledge necessary for performing key duties in financial management from an operational perspective' prevalent in 'most' municipalities (National Treasury 2011: 87). Clearly, this lack of technical skills seriously hampers the policy-making potential of municipalities in the area of property taxation. However, it is suggested that the national and provincial governments are also partly to blame for the deficiencies in property rates policies. The constitution is clear that national and provincial governments must support local government in developing its capacity (sections 154 and 155), and the national government is usually quick to boast about the co-operative nature of its system of decentralisation. Yet the reality is that the national government is unable to reach all municipalities with effective tailor-made capacity building. Meanwhile provincial governments, which are better suited to provide direct hands-on assistance, have not provided any meaningful support with regard to property rating, because it is not an area where they have developed any real capacity themselves. ${ }^{31}$ The result has been that most municipalities have had to rely on their own inadequate resources and capacity to craft property rates policies.

A more adequate system of supporting municipalities in drafting property rates policies would be likely to result in a more creative use of the scope offered by the MPRA. This support should take the form of not only training, guidelines and standardized templates, but also practical assistance to municipalities in making the necessary calculations and predictions in order to take informed policy decisions surrounding property rating. 
The examination of municipality policies in this research project suggests that it may have been rather ambitious to expect them to make considered choices about the potential of property rating to influence specific behaviour relevant to the developmental trajectory of their areas. It may also have been a tall order to expect municipalities to implement and justify those choices in a refined policy, and even predict and weigh up the budgetary consequences of those choices without access to advanced policy-making and modelling capacity. Nevertheless, municipalities may over time further explore the possibilities offered by the constitutional and policy framework, moving towards a more progressive and developmental system of property rating.

Thus a key lesson for other jurisdictions would be that the successful deployment of property rating as a developmental instrument is contingent on the provision of strong support to municipalities. This should include a robust legal framework that provides the necessary tools to creatively use property rating, insists on transparent policy-making and demands good administration. However, because expertise in rating administration is hard to come by, particularly in a developmental context, support needs to go further.

The South African experience shows that local discretion in designing rating policies may be desirable from a local democracy perspective, and offers opportunities for the adoption of policies that are tailored to local circumstances. But it also makes clear that the responsible design and implementation of instruments for rates alleviation that have a genuine developmental impact is a complicated task that may go beyond the capabilities of many a local authority. It is an activity that requires considerable capacity building through sectorwide initiatives and the close involvement of central (national or provincial) governments or international development bodies. 


\section{Notes}

1 The author wishes to thank Jelani Karamoko, research intern from Harvard Law School, who provided invaluable research assistance, and Tinashe Chigwata for editorial assistance. The research for this contribution was made possible by South Africa's National Research Foundation, the Ford Foundation and the Charles Stewart Mott Foundation.

${ }^{2}$ For a discussion of the history of local government and apartheid, see Steytler and De Visser (2007), De Visser (2005) and Ismail and Mpaisha (1997).

3 Compare, for example, Spain, with a population size of 44 million and a total number of 8,108 municipalities.

4 For example, access to electricity has increased by 10 per cent since 2001, flush toilets by 6 per cent and water by 4 per cent (Department of Cooperative Governance and Traditional Affairs 2009: 34).

5 The National Treasury cites a 'weak social contract at the local level, which finds expression in widespread unwillingness to pay for services' as a factor that compromises local government's ability to levy property rates (National Treasury 2011: 209). See also pages 23, 45 and 70 for references to the actions of ratepayer associations.

${ }^{6}$ City of Cape Town $v$ Robertson 2005 (3) BCLR 199 (CC) at para 62; CDA Boerdery (Edms) Bpk en 'n Ander $v$ Nelson Mandela Metropolitaanse Munisipaliteit en Andere [2005] JOL 14785 (SE) at para 6.

7 City of Cape Town $v$ Robertson 2005 (3) BCLR 199 (CC) at para 56.

8 Fedsure Life Assurance Ltd and Others $v$ Greater Johannesburg Transitional Metropolitan Council and Others 1998 (12) BCLR 1458 (CC) at para 39.

${ }_{9} \mathrm{CDA}$ Boerdery (SCA) at para 35.

${ }^{10} \mathrm{CDA}$ Boerdery (SCA) at para 40.

11 The ratio between conditional and unconditional grants has moved from 35/65 in the 2006/2007 financial year to 45/55 in 2008/2009 financial year (National Treasury 2011: 56).

12 At the end of 2010, municipalities were owed a total of R62.3 billion, an increase of 10.8 per cent from the same month in 2009 (National Treasury 2011: 61). However, both the National Treasury (2011: 61) and the Financial and Fiscal Commission (2011: 45) note that municipalities are making inroads in managing consumer debt.

13 This is buttressed by a warning in the constitution that 'fiscal capacity and efficiency' of municipalities must be taken into account in the calculation of their share of nationally generated income (see Constitution of the Republic of South Africa 1996, section 214(2)(e)). The fact that fiscal capacity and efficiency has not yet found a place in the equitable share formula points towards a failure to implement this constitutional instruction.

14 It has been suggested that municipalities should exempt owners who are recipients of old age or disability grants (Department of Provincial and Local Government [DPLG] 2005: 8).

15 For example, it has been suggested that indigents' properties should not be attached and sold because of their inability to settle rates liabilities (DPLG 2005: 7). 
16 The Department of Provincial and Local Government (DPLG) suggests that excessive rating of public service infrastructure may compromise the 'competitiveness of the local (municipal) economies and the entire South African economy vis-à-vis the international economy' (2005: 9).

17 Section 8(2) of the MPRA includes a list of categories, including categories such as residential, industrial, business and commercial, farm properties, smallholdings, state-owned properties, public service infrastructure, state trust land, communal land, properties owned by public benefit organisations etc. However, municipalities are free to determine their own categories, based on use, permitted use or geographical location.

18 S 3(3)(e) MPRA as amended by s 21(a) Local Government Law Amendment Act 19 of 2008.

19 See s 1(1) 'reduction' MPRA.

${ }^{20}$ See, for example, McKinlay Douglas (2006: 39-46) for an overview of the criticism of the public choice theory as the single platform for explaining local government's use. Section 2(1) of England's Local Government Act 2000 (c.22) postulates the economic, social and environmental well-being of the area of jurisdiction as the object for which local governments ought to use their powers. Section 174 of the recently adopted Constitution of Kenya posits 'equitable sharing of national and local resources throughout Kenya' as one of the objects of devolution of government. See also De Visser (2005: 19-32).

${ }^{21}$ See, for example, Department of Constitutional Development (1998, paragraph 2).

${ }^{22}$ S 25(d) Local Government: Municipal Demarcation Act 27 of 1998.

23 A large metropolitan municipality incorporating Durban.

24 Emfuleni is one of three local municipalities comprising the Sedibeng District Municipality situated in Gauteng Province. Mbomela (Nelspruit) is a middle-sized municipality and capital of Mpumalanga Province.

25 Msunduzi (Richard's Bay) is a large coastal municipality in KwaZulu-Natal.

26 Emalahleni is a local municipality situated in Mpumalanga Province, and is one of six in the Nkangala District Municipality. Mangaung (Bloemfontein) is a metropolitan municipality and capital of the Free State Province.

${ }_{27}$ Makhado (Louis Trichardt) is in Limpopo province. King Sabata Dalindyebo (Umthata) is a middlesized municipality in the Eastern Cape. Matjhabeng (Welkom) is in the Free State.

${ }^{28}$ For example, during the 2010-11 financial year the City of Cape Town forfeited R840 million in property rates revenue, which amounts to 16 per cent of its total property rates income. Its neighbour, Drakenstein Municipality, reported having foregone close to R41 million, which amounts to 21 per cent of its total property rates income. See City of Cape Town (2011: 167) and Drakenstein Municipality (2011: 165).

29 As at 31 December 2010, municipalities were owed a total of R62.3 billion. See National Treasury (2011: 60).

30 Confidence levels in local government are lower than in national and provincial governments, and have not been higher than 50 per cent since 2006. See LefkoEverett et al. (2011: 14).

\section{https://repository.uwc.ac.za}


${ }^{31}$ The proposed Local Government: Municipal Property Rates Amendment Bill (9 June 2011, Government Gazette 34357) includes provisions to compel provincial governments to take a greater interest in supporting municipal property rating. The Explanatory Memorandum is telling in that it predicts that, in order to implement these provisions, provincial departments responsible for local government 'will have to augment their establishments ... to perform hands-on monitoring of municipal implementation of the Act'. At the same time, the memorandum emphasises that they 'should ideally [already] have commensurate establishments if they are to fulfil their constitutional monitoring and support role'. See page 48 of the Bill. At the time of writing, the Bill had not been passed. 


\section{References}

African National Congress (2007), ANC Economic Transformation Policy Discussion

Document, African National Congress, Johannesburg, available at: www.anc.org.za/show.php?id=5246, (accessed 6 February 2013).

Ajam, $T$ (2001), 'Intergovernmental fiscal relations in South Africa', in Levy, $N$ and $C$ Tapscott (Eds), Intergovernmental Relations in South Africa: The Challenges of Co-operative Government, IDASA/School of Government, Cape Town, 125-142.

Bird, RM and E Slack (2004), 'Land and property taxation in 25 countries: a comparative overview', in Bird and Slack (Eds.), International Handbook of Land and Property Taxation, Edward Elgar, Cheltenham/Northampton, UK, 19-56.

City of Cape Town (2011), Annual Report 2010-11, City of Cape Town, Cape Town.

De Visser, J (2005), Developmental Local Government: A Case Study of South Africa, Intersentia, Antwerp.

De Visser, $J$ and D Powell (2012), Service Delivery Protest Barometer 2007-12, Multilevel Government Initiative, Community Law Centre, Cape Town, available at: www.mlgi.org.za/barometers/service-delivery-protest-barometer (accessed 6 February 2013).

Department of Constitutional Development (1998), White Paper on Local Government, Government Printers, Pretoria.

Department of Cooperative Governance and Traditional Affairs (2009), State of Local Government in South Africa National State of Local Government Assessments, Department of Cooperative Governance and Traditional Affairs, Pretoria.

Department of Provincial and Local Government (2005), Robust \& Inclusive Municipal Economies, Policy Guidelines for Implementing Local Economic Development in South Africa Pretoria, Department of Provincial and Local Government, Pretoria.

Drakenstein Municipality (2011), Annual Report 2010-2011, Drakenstein Municipality, Paarl.

Financial and Fiscal Commission (2011), 2012/2013 Submission for the Division of Revenue, Financial and Fiscal Commission, Pretoria.

Fjeldstad, $\mathrm{OH}$ (2001), 'Intergovernmental fiscal relations in the developing world: a review of issues', in Levy, $N$ and C Tapscott (Eds), Intergovernmental Relations in South Africa: The Challenges of Co-operative Government, IDASA/School of Government, Cape Town, 143-162.

Hickey-Tshangana, A (2009), Municipal Rates Policies and the Urban Poor - How can Municipal Rates Policies Promote Access by the Poor to Urban Land Markets?, SA Cities Network, Johannesburg.

Ismail, N and CJJ Mphaisha (1997), The Final Constitution of South Africa: Local Government Provisions and Their Implications, Occasional Papers Series, January, Konrad Adenauer Stiftung, Johannesburg.

Kihato, $M$ and $S$ Berrisford (2006), 'Regulatory systems and making urban land markets work for the poor in South Africa', paper prepared for the Urban Land Seminar, available http://www.urbanlandmark.org/downloads/o4 Kihato Berrisford.pdf (accessed 12 June 2012). 
Lefko-Everett K, A Nyoka and L Tiscornia (2011), 'SA reconciliation barometer', available at: www.reconciliationbarometer.org/ (accessed 6 February 2013).

McKinlay Douglas (2006), Local Government Structure and Efficiency, McKinlay Douglas, Tauranga.

National Treasury (2007), Local Government Budgets and Expenditure Review 2001/22007/8, National Treasury, Pretoria.

National Treasury (2011), Local Government Budgets and Expenditure Review: 2006/o72012/13, National Treasury, Pretoria.

Powell, D, A May and P Ntliziywana (2010), The Withholding of Rates in Five Local Municipalities, Community Law Centre, Cape Town.

Prud'Homme, R (1994), On the Dangers of Decentralisation, World Bank, Washington, DC.

Statistics South Africa (2007), South African Statistics, Statistics South Africa, Pretoria.

Steytler, N and J De Visser (2007), Local Government Law of South Africa, LexisNexis, Durban.

Western Cape Department of Environmental Affairs and Development Planning (2009), Western Cape Provincial Spatial Development Framework - Rural Land Use Planning \& Management Guidelines, Department of Development Planning and Environmental Affairs, Cape Town.

\section{Legislation}

Local Government: Municipal Property Rates Act, Act 6 of 2004.

Local Government: Municipal Property Rates Bill, 2011.

Local Government: Municipal Systems Act, Act 32 of 2000.

Constitution of the Republic of South Africa, 1996.

\section{Case law}

CDA Boerdery (Edms) Bpk en 'n Ander v Nelson Mandela Metropolitaanse Munisipaliteit en Andere [2005] JOL 14785 (SE).

City of Cape Town $v$ Robertson 2005 (3) BCLR 199 (CC).

Fedsure Life Assurance Ltd and Others $v$ Greater Johannesburg Transitional Metropolitan Council and Others 1998 (12) BCLR 1458 (CC). 
https://repository.uwc.ac.za 